\title{
Reducing Mutant Huntingtin Protein Expression in Living Cells by a Newly Identified RNA CAG Binder
}

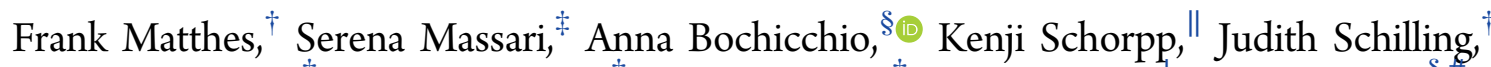

Stephanie Weber, ${ }^{\dagger}$ Nina Offermann, ${ }^{\dagger}$ Jenny Desantis, ${ }^{\dagger}$ Erich Wanker, ${ }^{\perp}$ Paolo Carloni, ${ }^{\S, \#}$ Kamyar Hadian, Oriana Tabarrini, ${ }^{*}$ Giulia Rossetti, ${ }^{*},, @, \nabla_{\odot}$ and Sybille Krauss ${ }^{*} \dagger$

${ }^{\dagger}$ German Center for Neurodegenerative Diseases (DZNE), Sigmund-Freud-Strasse 27, 53127 Bonn, Germany

${ }^{\ddagger}$ Department of Pharmaceutical Science, University of Perugia, Via del Liceo 1, 06123 Perugia, Italy

${ }^{\S}$ Computational Biomedicine, Institute for Advanced Simulation IAS-5 and Institute of Neuroscience and Medicine INM-9, Forschungszentrum Jülich, 52425 Jülich, Germany

"Assay Development and Screening Platform, Institute of Molecular Toxicology and Pharmacology, Helmholtz Zentrum München für Gesundheit und Umwelt, Ingolstädter Landstrasse 1, 85764 Neuherberg, Germany

${ }^{\perp}$ Neuroproteomics, Max Delbrück Center for Molecular Medicine, Robert-Rössle-Strasse 10, 13092 Berlin, Germany

\#JARA-HPC, Jülich Supercomputing Centre, Forschungszentrum Jülich GmbH, 52425 Jülich, Germany

${ }^{\circledR}$ Jülich Supercomputing Centre (JSC), Forschungszentrum Jülich, 52425 Jülich, Germany

${ }^{\nabla}$ Department of Hematology, Oncology, Hemostaseology, and Stem Cell Transplantation, Faculty of Medicine, RWTH Aachen University, Aachen, Germany

\section{Supporting Information}

\begin{abstract}
Expanded CAG trinucleotide repeats in Huntington's disease (HD) are causative for neurotoxicity. The mutant CAG repeat RNA encodes neurotoxic polyglutamine proteins and can lead to a toxic gain of function by aberrantly recruiting RNA-binding proteins. One of these is the MID1 protein, which induces aberrant Huntingtin (HTT) protein translation upon binding. Here we have identified a set of CAG repeat binder candidates by in silico methods. One of those, furamidine, reduces the level of binding of HTT mRNA to MID1 and other target proteins in vitro. Metadynamics calculations, fairly consistent with experimental data measured here, provide hints about the binding mode of the ligand. Importantly, furamidine also decreases the protein level of HTT in a HD cell line model. This shows that small molecules masking RNA-MID1 interactions may be active against mutant HTT protein in living cells.
\end{abstract}

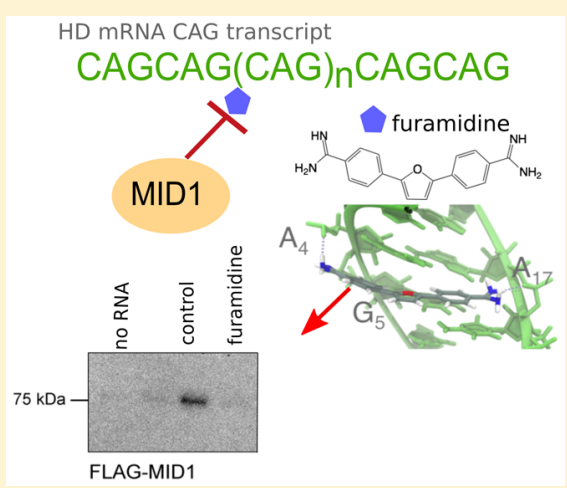

KEYWORDS: Huntington's disease, Metadynamics-based free energy calculations, Huntingtin protein, Living cell experiments, Furamidine, RNA-MID1 interactions

\section{INTRODUCTION}

Tandem repeats are short motifs of repeated nucleotides that occur frequently in the human genome, on average every 2000 base pairs. ${ }^{1}$ These repeats are unstable throughout meiosis and have a tendency to vary in length. ${ }^{2,3}$ The expansion of such short tandem repeats, for example CAG repeats, beyond a certain threshold, is linked to disease development. ${ }^{4}$

Huntington's disease (HD) is one of the best-known examples of CAG repeat expansion-based disorders. Here, the expansion is present in the coding region of the Huntingtin (HTT) gene. Normally, the CAG repeats in the latter gene comprise up to $36 \mathrm{CAG}$ repeats, while more than $40 \mathrm{CAG}$ repeats lead to HD. ${ }^{5}$ Unfortunately, $\mathrm{HD}$ is a devastating fatal neurodegenerative disease, for which there is no cure.

The disease-causing CAG repeat expansion mutation is translated into a polyglutamine tract in the HTT protein. The formation of mutant HTT protein aggregates is a pathological hallmark in HD patients' brains (reviewed in, e.g., ref 6). In addition to encoding the neurotoxic polyglutamine protein, a toxic gain of function of the mutant HTT mRNA has been suggested. ${ }^{7,8}$ HTT mRNA's single strands fold into a complex three-dimensional structure. ${ }^{9,10}$ In $\mathrm{HD}$, this structure features an additional loop due to the associated CAG expansion. ${ }^{7}$ This loop is predicted to be a duplex hairpin structure. ${ }^{7}$ Here, C-G and G-C base pairs are followed periodically by nonstandard AA mismatches. ${ }^{7}$ The two A's face each other and are shifted out of the helical axis toward the major groove. ${ }^{11}$ As a result, the CAG repeat's helical structure is unwound and forms a

Received: January 19, 2018

Accepted: March 5, 2018

Published: March 5, 2018 
bubble. ${ }^{11}$ The size and stability of the hairpin increase with an increasing repeat length. ${ }^{7}$ Hence, the gain of function can be explained by a recruitment of RNA-binding proteins by expanded CAG repeat mRNAs, leading to loss of normal function and, potentially, to aberrant protein function when they are bound to the pathogenic CAG repeat (reviewed, for instance, in refs 7 and 8). In particular, one of us (S.K.) has shown that binding of the MID1 protein to mRNA results in increased protein translation of neurotoxic mutant HTT protein. $^{12}$

In this paper, we investigate the effect of ligands potentially targeting CAG repeats in living cells ${ }^{a}$ using a novel strategy. We attempt to mask CAG repeat RNA from the interaction with MID1 protein using small compounds. If this is the case, the presence of these ligands may lead to a reduction of HTT protein synthesis, because the formation of the MID1-RNA complex induces protein translation of HTT mRNA. ${ }^{12}$ Our study is performed in several steps. First, we use in silico methods to identify a set of commercially available CAG repeat binder candidates. Then, we test whether the selected compounds decrease the binding of HTT exon1 RNA to RNA-bound proteins, including MID1, in an RNA pull-down assay in vitro. Finally, if this is the case, we test if the compounds reduce aberrant HTT protein levels in HD living cells.

We find that furamidine (Figure 1c), one of the selected molecules, does inhibit the recruitment of MID1 to mutant

a

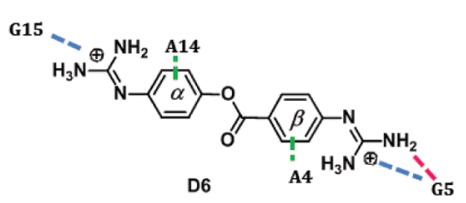

b

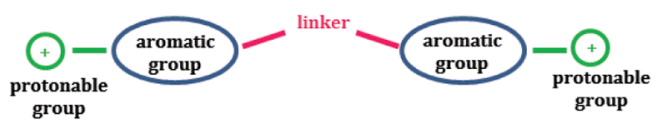

C
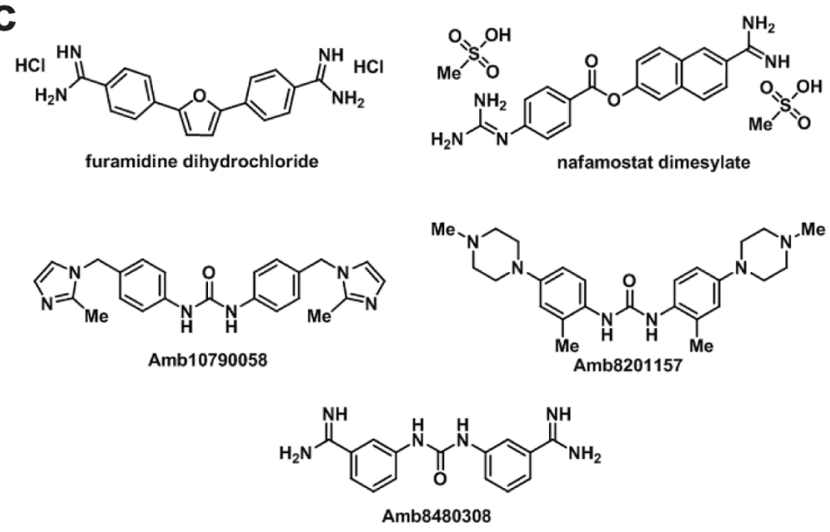

Figure 1. (a) Chemical structure of the D6 molecule ${ }^{15}$ (4guanidinophenyl 4-guanidinobenzoate derivative). D6 binds in vitro to CAG repeats in the low nanomolar range. ${ }^{15}$ (b) General structure of CAG binders emerging from our previous computational study. ${ }^{16}$ (c) Small library of CAG binder candidates. Their protonation state in aqueous solution and at physiological $\mathrm{pH}(\sim 7.4)$ was assessed by predicting the aqueous ionization constant $\left(\mathrm{p} K_{\mathrm{a}}\right)$ using Marvin version 5.2. ${ }^{17}$
HTT RNA CAG repeats and decreases the HTT protein content in HD living cells. Molecular simulations, in good agreement with the measured affinity of the compound in vitro, suggest that the binding to CAG repeat is not very specific.

\section{RESULTS AND DISCUSSION}

CAG Repeat Binder Candidates. The structural determinants of a ligand [D6 (Figure 1)] with a high affinity for CAG repeat $\mathrm{RNA}^{\mathrm{P}}$ and a CAG-containing RNA duplex, predicted by our team, ${ }^{16}$ are the starting points for the in silico identification of CAG repeat binder candidates. Our in silico model of the D6-RNA complex suggests that binding of D6 to CAG repeats occurs via (i) two salt bridges between the positively charged guanidine tails and the $G_{15}$ and $G_{5}$ phosphates, (ii) an $H$-bond between the amino group of the guanidine moiety linked to the $\beta$ ring and the $\mathrm{O5}^{\prime}\left(\mathrm{G}_{5}\right)$ atom, and (iii) parallel ( $\beta$ ring) and Tshaped ( $\alpha$ ring) $\pi$-stacking interactions with two adenines of the CAG repeat (Figure 1a). ${ }^{16}$ On the basis of this information, we searched the Scifinder database for compounds that feature (i) two aromatic rings, which may form interactions with the two adenines, (ii) a linker spacing the two aromatic moieties, such as amide, urea, ketone, ether, or a furan ring, and (iii) two protonable moieties placed on the two aromatic rings, such as guanidines, amidines, and nitrogen-containing aliphatic or aromatic rings, ensuring the salt bridges with the guanine phosphates (Figure 1b). Twenty-five molecules were initially selected on the basis of the highest chemical diversity (Table S1). Among them, considering their cost and supplier availability, a set of five compounds was chosen for in vitro tests (Figure 1c): (i) furamidine, which presents a furan ring as a linker between two phenyl moieties (D6's guanidines are replaced with amidines), (ii) nafamostat mesylate, which is an ester derivative in which a phenyl is replaced with a quinoline ring, and (iii-v) Amb8480308, Amb8201157, and Amb10790058, in which a urea moiety links the two phenyl rings that bear amidines, imidazoles, and methylpiperazines as protonable groups, respectively.

Effect on HTT mRNA. As a next step, we investigated whether the selected compounds (Figure 1c) interfere with the binding of MID1 to HTT exon1 RNA (i) and, if so, whether they reduce HTT protein synthesis in HD living cells (ii).

Effect of Compounds on Binding of MID1 to HTT mRNA. In vitro transcribed HTT exon 1 RNA with 72 CAG repeats was biotinylated and incubated with protein extracts from FLAGMID1-expressing HEK293T cells to allow RNA-protein binding. Biotinylation of the RNA allowed immobilization of the RNA-protein complexes on streptavidin-coated beads. These RNA-protein complexes were incubated in the presence or absence of the selected compounds at a concentration of 100 $\mu \mathrm{M}$. After extensive washing, the RNA-bound proteins were eluted and analyzed on a Western blot detecting FLAG-MID1. As expected, in the positive control sample without compound treatment, FLAG-MID1 bound to the HTT exon1 RNA, whereas the negative control using beads only (without RNA) showed no signal. Furamidine turned out to inhibit the binding of FLAG-MID1 to HTT exon1 RNA (Figure 2a and Figure S1). A similar RNA pull-down assay also using smaller doses of furamidine $(50 \mu \mathrm{M})$ leads to a clear reduction of binding of MID1 to HTT RNA. At even smaller doses, this effect was not seen (Figure 2b).

To test if furamidine decreases the binding of other RNAbinding proteins to HTT exon1 RNA, we repeated the RNA pull-down assay and analyzed all RNA-bound proteins by silver 

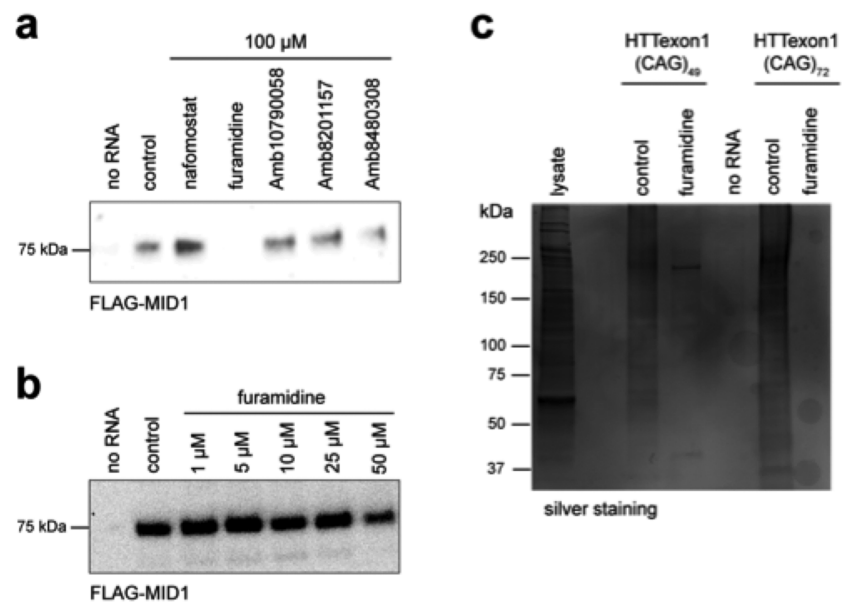

Figure 2. Furamidine reduces the binding of HTT exon1 RNA to RNA-binding proteins. (a) RNA-protein pull-down of HTT exon1 RNA and its interacting protein MID1. Beads coated with HTT exon1 RNA containing 72 CAG repeats or without RNA (beads, negative control) were incubated with protein extracts of FLAG-MID1expressing HEK293T cells in the presence or absence of the following compounds at a concentration of $100 \mu \mathrm{M}$ : furamidine, nafomostat, Amb10790058, Amb8201157, and Amb8480308. Eluted RNA-bound proteins were analyzed on Western blots detecting FLAG-MID1. (b) RNA-protein pull-down of HTT exon1 RNA containing 72 CAG repeats and its interacting protein MID1 or without RNA (beads, negative control) in the presence or absence of furamidine at concentrations of $1,5,10,25$, and $50 \mu \mathrm{M}$. RNA-bound proteins were analyzed on Western blots detecting FLAG-MID1. (c) RNA-protein pull-down of HTT exon1 RNA and its interacting protein MID1. Beads coated with HTT exon1 RNA containing 49 or 72 CAG repeats or without RNA (beads, negative control) were incubated with protein extracts of FLAG-MID1-expressing HEK293T cells in the presence or absence of $100 \mu \mathrm{M}$ furamidine. All RNA-bound proteins were visualized by silver staining of proteins in a polyacrylamide gel.

staining. Treatment with $100 \mu \mathrm{M}$ furamidine also reduced the binding of other RNA-binding proteins to HTT exon1 RNA containing 49 or 72 CAG repeats (Figure $2 c$ ).

The other compounds in Figure 1 did not significantly affect the binding and were not investigated further.

(ii) Effect of Furamidine on MID1-Dependent Protein Synthesis in Cell-Based Assays. Here we used two HD cell line models, HEK293T cell lines that stably express FLAG-tagged HTT exon 1 with either 51 or 83 CAG repeats under an inducible promoter, and treated these cells with furamidine. HTT protein levels were analyzed on Western blots for the cells expressing HTT exon 1 with 51 CAG repeats or on a filter trap assay for the cells expressing HTT exon1 with 83 CAG repeats. In both cell lines, we observed a clear reduction of HTT exon1 polyglutamine protein levels after furamidine treatment, whereas mRNA levels were not decreased (Figure $3 a-d)$. It is noteworthy that, in the same cells, protein levels of other nonmutant polyglutamine proteins were not affected (Figure S2). At the concentrations used here, furamidine did not induce cytotoxicity (Figure $3 \mathrm{e}$ ). In the cellular setup described above, a putative effect of furamidine on protein stability rather than on protein translation cannot be excluded. To further investigate whether furamidine indeed affects protein translation, we performed an in vitro translation assay. A firefly luciferase reporter sequence fused to HTT exon1 with 47 CAG repeats was in vitro transcribed and the purified RNA subsequently subjected to in vitro translation in the presence or absence of furamidine. We observed a dose-dependent reduction of luciferase reporter translation in the presence of furamidine (Figure 3f).

To validate that furamidine reduces the protein translation rate of HTT exon1, we used a previously established fluorescence recovery after photobleaching (FRAP)-based technique to monitor protein translation in living cells. For this experiment, HTT exon 1 fused to green fluorescent protein (GFP) was expressed in HeLa cells. After the entire cell is bleached, the fluorescence signal of GFP-HTT exon1 is lost, allowing researchers to capture the signal recovery of newly translated GFP-tagged protein over time. ${ }^{12,18}$ While in untreated cells the expected recovery of fluorescence was observed, treatment of cells with furamidine significantly reduced the protein translation rate (Figure 4a). It is noteworthy that, in a similar FRAP-based assay for monitoring translation of GFP only, no significant reduction of GFP translation was observed after furamidine treatment, indicating that the effect is specific for the HTT exon1-CAG47 sequence (Figure 4b). At the concentrations used in this FRAP-based translation assay, furamidine did not induce cytotoxicity in HeLa cells (Figure 4c).

Furamidine enters cells efficiently (and then accumulates intracellularly) most probably aided by specific transporters. ${ }^{19,20}$ Here we show that furamidine's intracellular concentration is higher than the concentration in the medium. This semiquantitative information was obtained by the mass spectrometry method with cell volume estimation.

HeLa cells were treated with $50 \mu \mathrm{M}$ furamidine. The intracellular concentration after $5 \mathrm{~h}$ was $74.5 \pm 3.1 \mu \mathrm{M}$. Together, these data suggest that furamidine inhibits the binding of RNA-interacting proteins such as MID1 to HTT mRNA, thereby inhibiting protein translation. In the assays mentioned above, we used HTT exon 1 constructs that, in addition to the CAG repeat, also contained some repeats flanking sequences. Thus, we cannot rule out the possibility that furamidine acts exclusively on the repeat flanking region and not at all on the CAG repeats themselves. To investigate this issue, we created a luciferase reporter construct containing a pure $(\mathrm{CAG})_{50}$ repeat in its $3^{\prime}$-UTR. As a control, we used the empty vector expressing luciferase without CAG repeats. These constructs were transfected into HEK293T cells that subsequently underwent furamidine treatment.

While furamidine had a slight but not significant effect on the control without CAG repeats, it significantly reduces reporter expression of the construct containing the pure CAG repeats (Figure 5). This suggests that furamidine does bind to CAG repeats and not only to the HTT repeat flanking sequence in HEK293T cells.

Mode of Binding of Furamidine to CAG Repeats. As a final step in our investigation, we predicted the mode of binding of furamidine to CAG repeats. For this purpose, we calculated the free energy surface (FES) of furamidine binding to a model CAG RNA, using well-tempered metadynamicsbased simulations, which was done for compound D6. ${ }^{16}$ Comparison was then made with experimental affinity data measured here.

The calculated free energy landscape is characterized by several basins that are not too dissimilar in free energy ( $B$ and M1-M4 in Figure 6). In the lowest-free energy basin B, the molecule binds to the RNA major groove, forming salt bridges with the $A_{4}, G_{5}$, and $A_{17}$ phosphate groups (Figure 6) as for the D6-CAG complex. ${ }^{16}$ The furan and the other phenyl ring are 

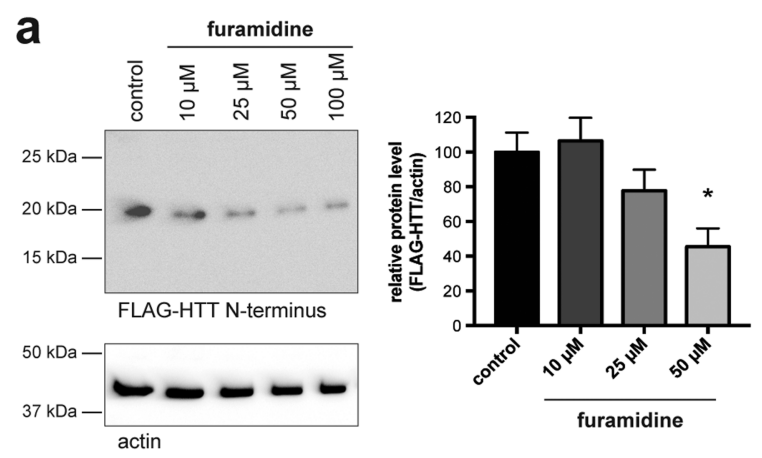

b
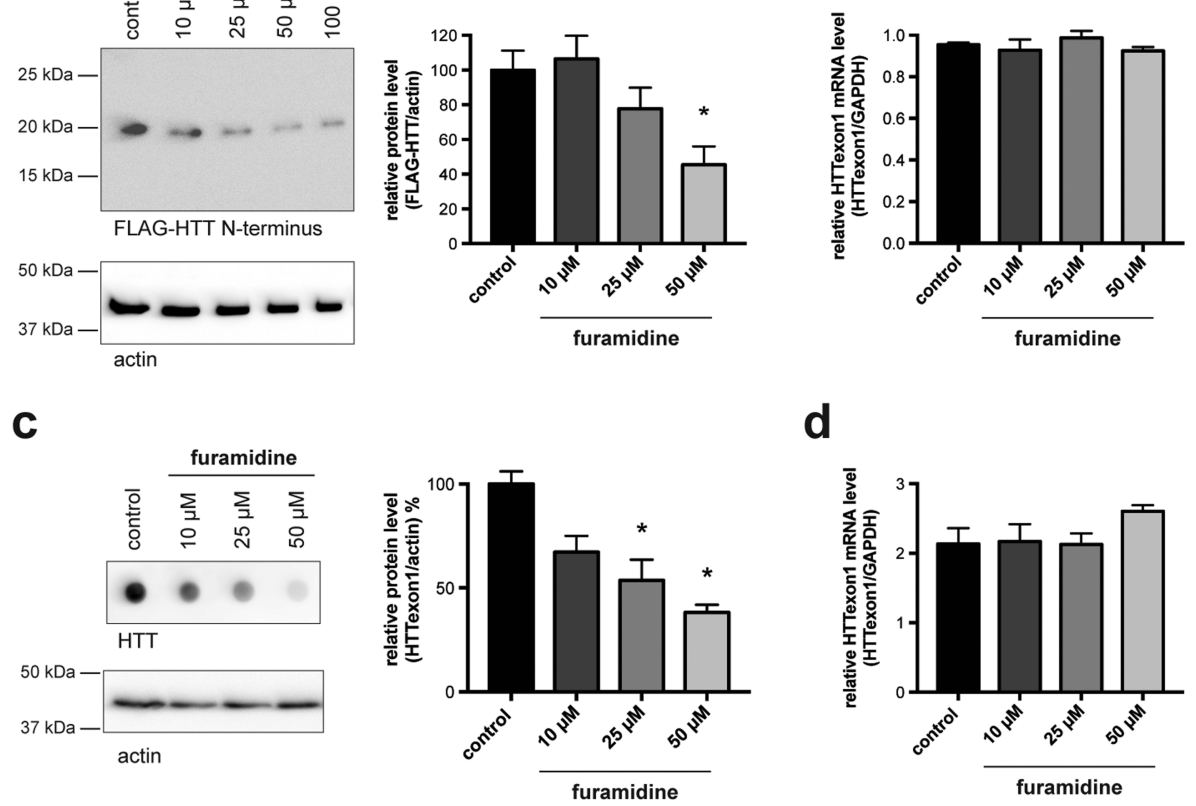

d
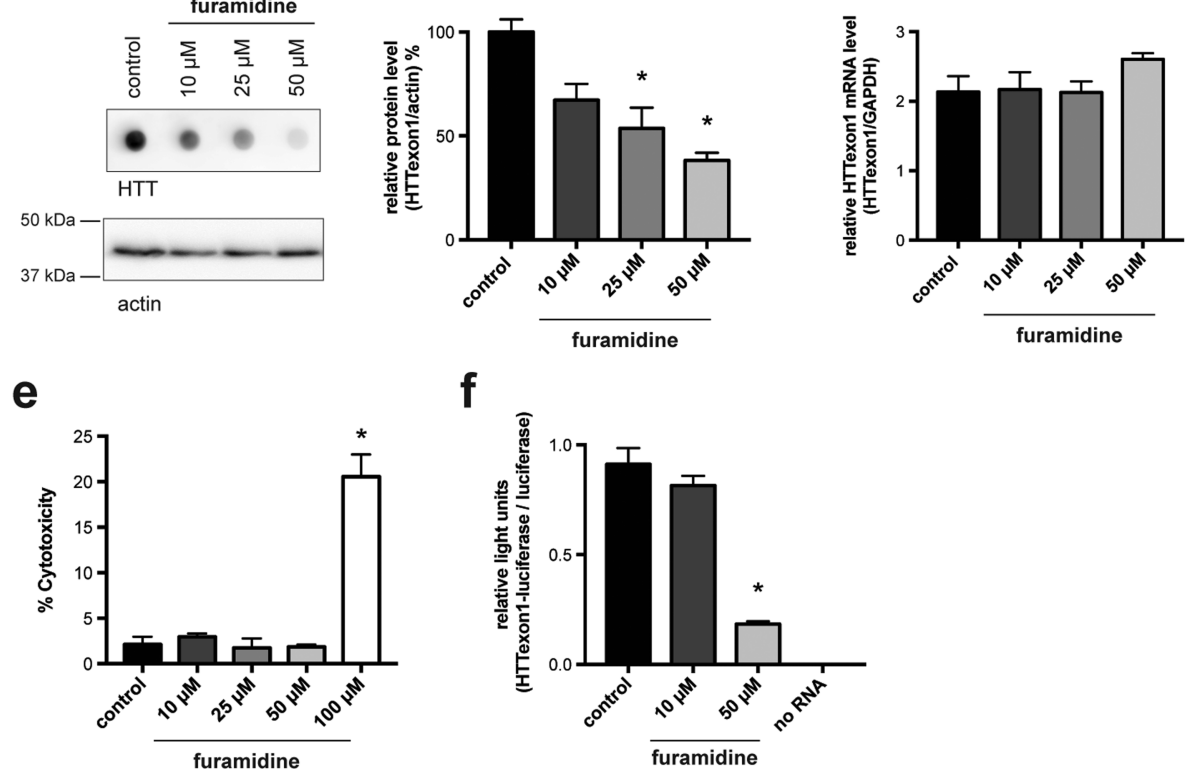

Figure 3. Furamidine reduces the protein level of HTT exon1 polyglutamine protein in HD cell line models. (a) HEK293T cells stably expressing FLAG-tagged HTT exon1 with 51 CAG repeats were treated with or without different doses of furamidine for $24 \mathrm{~h}$. The HTT exon1 protein level was analyzed on a Western blot using anti-HTT antibodies for detection. Actin was detected as a loading control. (b) The HTT exon1 RNA level in cells described for panel a was analyzed by real-time polymerase chain reaction. Mean values \pm the standard error of the mean $($ SEM $)$ are shown $(n=$ 12). (c) HEK293T cells stably expressing FLAG-tagged HTT exon1 with 83 CAG repeats were treated with or without different doses of furamidine for $24 \mathrm{~h}$. The HTT exon 1 protein level was analyzed on a filter trap assay using anti-HTT antibodies for detection. Actin was detected on a Western blot as a loading control. (d) The HTT exon1 RNA level in cells described for panel $\mathrm{c}$ was analyzed by real-time polymerase chain reaction. Mean values \pm SEM are shown $(n=12)$. (e) HEK293T cells stably expressing FLAG-tagged HTT exon1 with 51 CAG repeats were treated with or without different doses of furamidine for $24 \mathrm{~h}$. The cytotoxicity of furamidine treatment was measured in an LDH assay. Columns represent the percent cytotoxicity $\pm \operatorname{SEM}\left(n=3{ }^{*} p=0.0001\right)$. (f) In vitro translation. A luciferase reporter containing HTT exon1 with 47 CAG repeats in its $3{ }^{\prime}-$ UTR or luciferase without HTT exon1 was in vitro transcribed and subjected to in vitro translation in the absence (control) or presence of increasing doses of furamidine. Relative light units of the luciferase reporter fused to HTT exon1 with 47 CAG repeats normalized to luciferase without HTT exon 1 are shown. Columns represent mean values \pm SEM $(n=3 ; p \leq 0.001)$.

fully solvent exposed. Two salt bridges between the ligand amidine tails and the phosphate groups of nucleotides $\mathrm{G}_{5}$ and $\mathrm{G}_{2}$ are also observed.

A detailed description of the binding poses of the other minima and the way these have been identified is reported in Methods and in the Supporting Information.

The unbinding free energy $(-7.5 \mathrm{kcal} / \mathrm{mol})$ is estimated by computing the free energy difference between basin $\mathrm{B}$ and the isoenergetic states in the unbound region, $U$ in Figure 6. The residual unbinding free energy on passing from minimum $U$ to a complete separation of the ligand $(-2.1 \pm 0.6 \mathrm{kcal} / \mathrm{mol})$ was estimated by using the nonlinear Poisson-Boltzmann equation. Hence, the calculated total unbinding free energy is approximately $-9 \mathrm{kcal} / \mathrm{mol}$. The resulting standard state binding free energy $\left(\Delta G_{\text {calc }}^{0}\right)$, which takes into account the concentration of the ligand in our simulation, gives a value of apprioximately $-7 \mathrm{kcal} / \mathrm{mol}$.

We now compare this value with a measurement of the binding affinity measure with microscale thermophoresis (MST). This is the directed movement of particles in a microscopic temperature gradient and can be used for binding analysis of biomolecules. Changes in the hydration shell of biomolecules due to binding to other biomolecules result in a relative change in the movement along the temperature gradient, which can be used to determine binding affinities. We have used MST to investigate the association of furamidine with Cy5-labeled HTT exon1 RNA with different CAG repeat lengths. A serial dilution of furamidine was added with a starting concentration of $1 \mathrm{mM}$ to the corresponding nucleic acid. Sigmoidal binding curves could be detected, with the 

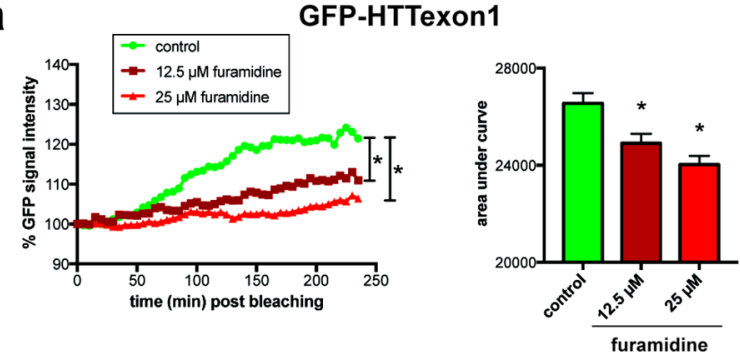

b

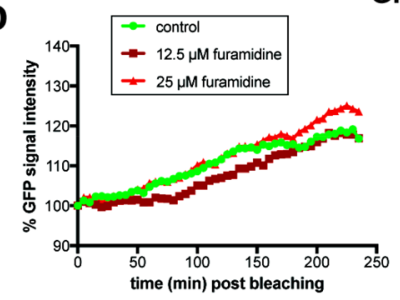

GFP

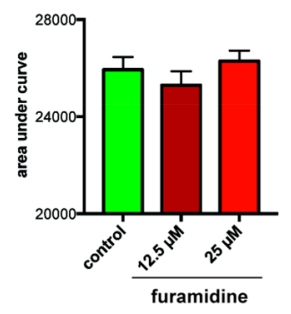

C

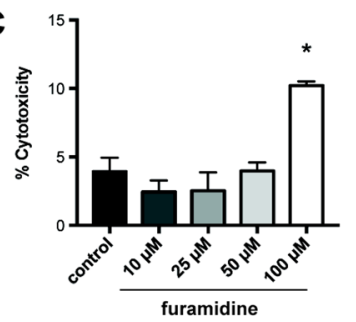

Figure 4. Furamidine reduces the protein translation of GFP-HTT exon1. (a) FRAP-based assays for monitoring translation in living cells were performed in HeLa cells transfected with GFP-HTT exon1. Cells were bleached with a high-intensity laser. Translation was monitored by analyzing the recovery of the GFP signal in living cells over $4 \mathrm{~h}$. Lines represent mean values over time. Assays were performed in quintuplicate with several cells per experiment $\left(n_{\text {control }}=36 ; n_{12.5} \mu \mathrm{M}=\right.$ 36; $\left.n_{25 \mu \mathrm{M}}=43\right)$. Statistics were determined using one-way analysis of variance (ANOVA) $(* p<0.0001)$. Columns represent the area under the curve $(* p<0.01)$. (b) FRAP-based assays for monitoring translation in living cells were performed in HeLa cells transfected with GFP. Cells were bleached with a high-intensity laser. Translation was monitored by analyzing the recovery of the GFP signal in living cells over $4 \mathrm{~h}$. Lines represent mean values over time. Assays were performed in quintuplicate with several cells per experiment $\left(n_{\text {control }}=\right.$ $\left.51 ; n_{12.5 \mu \mathrm{M}}=38 ; n_{25 \mu \mathrm{M}}=38\right)$. Statistics were determined using oneway ANOVA ( $p>0.05$, not significant). Columns represent the area under the curve $(p>0.05$, not significant). (c) Furamidine cytotoxicity in HeLa cells. HeLa cells were treated with or without different doses of furamidine for $24 \mathrm{~h}$. The cytotoxicity of furamidine treatment was measured in an LDH assay. Columns represent the percent cytotoxicity $\pm \operatorname{SEM}(n=3 ; * p=0.006)$.

shorter RNA (CAG18) displaying an MST response that is stronger than that of the longer version (CAG48). For the binding of furamidine to Cy5-CAG18, we determined a $K_{\mathrm{D}}$ of $59.9 \pm 8.61 \mu \mathrm{M}$ (Figure 7), while using CAG48, a $K_{\mathrm{D}}$ of $160 \pm$ $15.1 \mu \mathrm{M}$ was measured. The MST-derived binding free energy $\left[\Delta G^{\mathrm{MST}} \approx-5 \mathrm{kcal} / \mathrm{mol}\right.$ (Methods) $]$ is similar to the calculated one.

\section{CONCLUSIONS}

RNA-mediated toxicity is a phenomenon underlying several CAG repeat expansion disorders. Toxic functions of an expanded CAG repeat RNA can be explained by aberrant recruitment of diverse proteins to the mutant CAG repeat RNA. $^{7,8}$ Mutant CAG repeat RNAs fold into hairpin structures

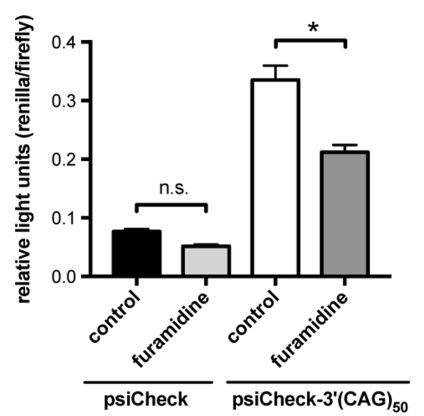

Figure 5. Luciferase reporter assay. A Renilla luciferase reporter construct containing 50 CAG repeats in its $3^{\prime}$-UTR was expressed in HEK cells that underwent furamidine treatment. Firefly luciferase, expressed from the same plasmid, was used for normalization. As a control, a plasmid without CAG repeats was used. Columns represent mean values $\pm \operatorname{SEM}(n=12$; ns $p=0.5951 ; * p<0.0001)$.

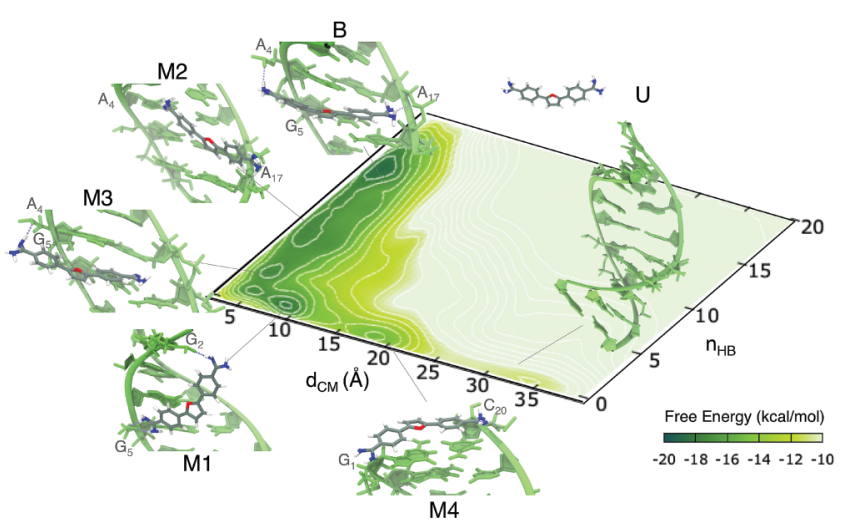

Figure 6. Bidimensional representation of the free energy surfaces associated with furamidine-CAG RNA interactions. The free energy is plotted as a function of the distance between the CAG RNA and ligand centers of mass $\left(d_{\mathrm{CM}}\right)$ and as a function of the number of hydrogen bonds formed by the two moieties $\left(n_{\mathrm{HB}}\right)$. Energy is given in units of kilocalories per mole. B denotes the bound state, while U represents the unbound state minimum. M1-M4 are local minima. For each minimum, representative cartoon representations are provided.

that provide the surface for such aberrant RNA-protein interactions. One example of an RNA-binding protein that is captured by expanded CAG repeat mRNA is the MID1 protein, ${ }^{12,21}$ which induces aberrant protein translation upon binding.

Here, we performed biological assays with a set of CAG repeat binder candidates identified here in silico. One of those, furamidine, turned out to bind to HTT exon1 RNA in vitro and to reduce the binding of MID1 to HTT mRNA. The in vitro RNA-protein pull-down experiments show reduced binding of MID1 to CAG repeat RNA (and other RNA-binding proteins) in the presence of furamidine, albeit for rather high concentrations $(>50 \mu \mathrm{M})$. Hence, furamidine competes for binding to proteins like MID1 to CAG repeat RNA. Furamidine is further shown to bind directly to the CAG repeats. To provide a molecular basis of the mode of binding of furamidine to the CAG repeats, we have performed free energy calculations on a RNA duplex. Our prediction of the affinity is similar to that emerging from our in vitro experiments, validating our approach. The calculations predict several rather different, similarly populated binding poses. This is consistent with the relatively low affinity of the compound in silico and in 
a

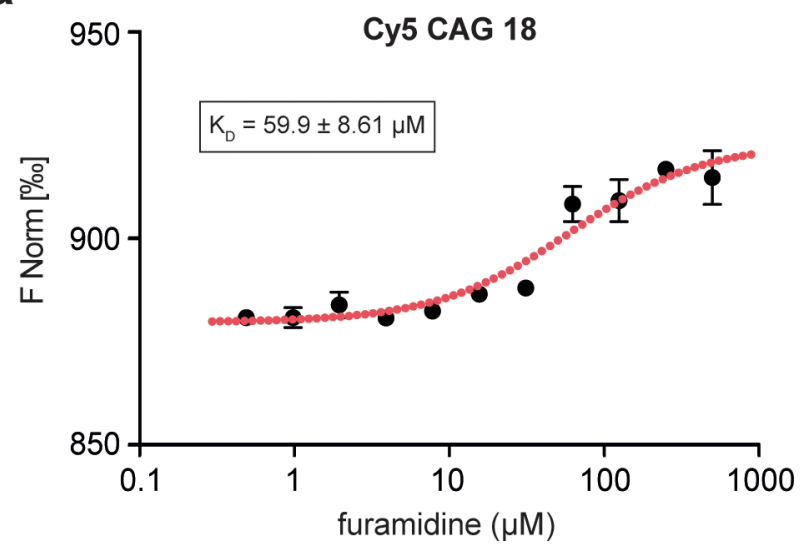

b

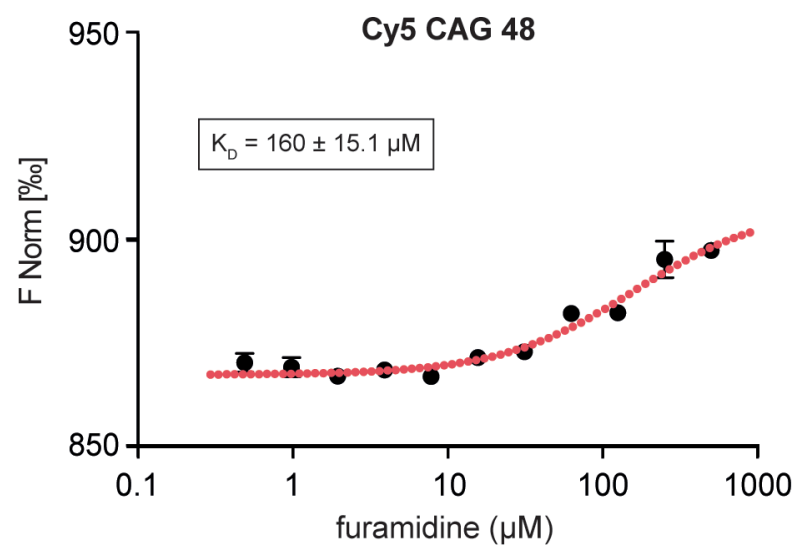

Figure 7. Determination of the dissociation constant of the furamidine-HTT exon1 RNA interaction by MST. Here Cy5-labeled HTT exon1 RNA was analyzed in the presence of furamidine at increasing concentrations. (a) HTT exon1 CAG18 RNA and (b) HTT exon1 CAG48 RNA were monitored by titrating furamidine from 500 $\mu \mathrm{M}$ to $\sim 15 \mathrm{nM}$ against $400 \mathrm{nM}$ Cy5-labeled RNAs. Changes in thermophoresis were plotted and yielded $K_{\mathrm{D}}$ values of (a) $59.9 \pm 8.61$ and (b) $160 \pm 15.1 \mu \mathrm{M}$. Error bars are SEM $(n=3)$.

vitro. Hence, the ligand might bind in a rather unspecific manner to CAG repeat RNA.

We conclude that furamidine is able to reduce the binding of MID1 to HTT mRNA in vitro. The compound also reduces protein levels of HTT in an HD cell line model, which is consistent with the relevance of this binding event for protein translation of HTT mRNA. ${ }^{12}$

Do these results have direct implications for the development of furamidine as an anti-HD drug? We believe that this may not be the case, for several reasons. Indeed, real drugs need to have a higher affinity for mutant CAG repeats. In addition, the activity of furamidine is not specific for CAG repeat RNA repeats. In particular, it may bind AU RNAs, ${ }^{22}$ CUG RNAs, ${ }^{23}$ and even the DNA minor groove (AT). ${ }^{24}$ Therefore, if one were to treat disease models with furamidine, off-target effects would be expected. In line with that notion, furamidine is not ideal for clinical use, a conclusion that emerged from Phase III trials of its prodrug pafuramidine. ${ }^{25}$ Instead, of course, the strategy adopted here, which uses in vitro assays of binding of MID1 to HTT mRNA in the presence of small molecules, could be used in the future to identify interesting new leads for anti-HD therapy.
In conclusion, we have shown here that it is generally possible to mask CAG repeat RNA from its target MID1 protein with a small compound like furamidine, which in turn may decrease HTT levels in living cells.

\section{METHODS}

Compounds. Compounds used in this study were purchased from Toronto Research Chemicals (furamidine dihydrochloride, catalog no. F863600), Sigma-Aldrich (nafamostate mesylate, catalog no. N0289), and Ambinter (Amb8480308, Amb8201157, and Amb10790058). The purity of the compounds was measured by the supplier using highperformance liquid chromatography and ensured to be $>95 \%$.

RNA Pull-Down. HTT exon1 mRNA fragments containing 49 or 72 CAG repeats were amplified by polymerase chain reaction (PCR) (forward primer, CCAAGCTTCTAATACGACTCACTATAGGGAGAATGGCGGACCCTGGAAAAGCTGATGAAGG; reverse primer, GGTCGGTGCAGCGGCTCCTCAGC) using plasmids as templates (HTT exon1 with 49 or 72 CAG repeats cloned into the multiple cloning site of pEGFP-C1). The PCR products were treated with proteinase $\mathrm{K}$ and purified by phenol/chloroform extraction. One volume of a 25:24:1 phenol/chloroform/isoamyl alcohol mixture was added to each sample, and samples were rotated for $10 \mathrm{~min}$ and centrifuged at $12000 \mathrm{~g}$ for $5 \mathrm{~min}$. The aqueous upper phase was transferred to a new tube; 1 volume of chloroform was added, and samples were rotated for $10 \mathrm{~min}$ and centrifuged at $12000 \mathrm{~g}$ for $5 \mathrm{~min}$. The aqueous upper phase was transferred to a new tube and precipitated with 2.5 volumes of $95 \% \mathrm{EtOH}$ and $400 \mathrm{mM} \mathrm{LiCl}$ at -20 ${ }^{\circ} \mathrm{C}$ for $>30 \mathrm{~min}$. After centrifugation at $12000 \mathrm{~g}$ for $20 \mathrm{~min}$ in a microcentrifuge at $4{ }^{\circ} \mathrm{C}$, the pellet was washed with $75 \% \mathrm{EtOH}$ and air-dried. The pellet was resuspended in nuclease free $\mathrm{H}_{2} \mathrm{O}$. In vitro transcription of the purified PCR products was performed using the RiboMAX large scale RNA production system T7 (Promega) in combination with biotinylated UTP. The resulting biotinylated RNAs were incubated with $10 \mu \mathrm{L}$ of DNaseI for $30 \mathrm{~min}$ at $37^{\circ} \mathrm{C}$ and purified by phenol/chloroform extraction. HEK293T cells expressing FLAGMID1 were lysed in buffer D [ $20 \mathrm{mM}$ Tris ( $\mathrm{pH} 7.9$ ), $20 \%$ glycerol, 0.1 $\mathrm{M} \mathrm{KCl}, 0.2 \mathrm{mM}$ EDTA, $0.5 \mathrm{mM}$ DTT, protease inhibitor, and RNase inhibitor] using the precellys cell homogenizer; $40 \mathrm{pmol}$ of purified RNA was added to $20 \mu \mathrm{L}$ of streptavidin-agarose beads (life technologies) per sample. Then, $100 \mu \mathrm{L}$ of HEK293T protein extract was added per sample, and the volume was increased to $1 \mathrm{~mL}$ with buffer $\mathrm{D} ; 200 \mu \mathrm{g}$ of yeast $\mathrm{RNA} / \mathrm{mL}$ was added per sample. The respective compounds were added at a final concentration of $100 \mu \mathrm{M}$, and samples were incubated by being rotated at $4{ }^{\circ} \mathrm{C}$ overnight. Beads were washed three times with $1 \mathrm{~mL}$ of buffer $\mathrm{D}$, and RNA-bound proteins were analyzed on a Western blot.

Treatment of Cell Lines. HEK293T cells stably expressing FLAGtagged HTT exon1 with either 51 or 83 CAG repeat under an inducible Tet-Off promoter ${ }^{26}$ were used for treatment with different doses of furamidine. Washing off doxycycline induced the expression of HTT exon1, and furamidine was added to the culture medium. Cells were then cultured for 24-48 h, washed with PBS, and harvested using a cell scraper. Cells expressing HTT exon1 with 51 CAG repeats were lysed in RIPA buffer; sample buffer was added, and the lysates were denaturated for $5 \mathrm{~min}$ at $95{ }^{\circ} \mathrm{C}$ and subsequently separated on Tris-Tricine precast gels (Bio-Rad) and subjected to Western blotting. Cells expressing HTT exon 1 with 83 CAG repeats were subjected to a filter trap assay.

Filter Trap Assay. Filter retardation assays were performed as described previously. ${ }^{26}$ In brief, cell pellets were resuspended in lysis buffer [ $50 \mathrm{mM}$ Tris ( $\mathrm{pH} 8.8$ ), $100 \mathrm{mM} \mathrm{NaCl}, 5 \mathrm{mM} \mathrm{MgCl}, 1 \% \mathrm{NP}-$ 40, $1 \mathrm{mM}$ EDTA ( $\mathrm{pH} 8)$, and Benzonase $(5 \mu \mathrm{L} / 20 \mathrm{~mL}$ of lysis buffer)], and the concentration was adjusted to $1 \mathrm{mg} / \mathrm{mL} ; 350 \mu \mathrm{L}$ of protein lysate $(1 \mathrm{mg} / \mathrm{mL})$ was mixed with $350 \mu \mathrm{L}$ of denaturing buffer [100 mM DTT and 4\% sodium dodecyl sulfate (SDS)] and incubated at $98{ }^{\circ} \mathrm{C}$ for $7 \mathrm{~min}$. Samples were then passed through a celluloseacetat membrane (Whatman Membrane Filter, Celluloseacetat, $0.2 \mu \mathrm{M}, 300$ $\mathrm{mm} \times 600 \mathrm{~mm} \times 5 \mathrm{~mm}$, catalog no. 10404180) using a HYBRI-DOT MANIFOLD (BRL, catalog no. 1050MM). Membranes were blocked 
in 5\% nonfat skim milk powder in TBST, and HTT aggregates on the membrane were detected by incubating the membrane with an antiFLAG antibody at $4{ }^{\circ} \mathrm{C}$ overnight (anti-FLAG HRP-coupled, A8592 Sigma, 1:2000 dilution in TBST). Six replicates were analyzed $(n=6)$. The resulting dots were quantified using AIDA software (Raytest). Data shown represent means \pm SEM. Statistical significance was evaluated using the $t$ test (two-tailed, homoscedastic).

Cytotoxicity Assay. Either HeLa or HEK293T cells stably expressing FLAG-tagged HTT exon1 with 51 CAG repeats under an inducible Tet-Off promoter $^{26}$ were used. Washing off doxycycline induced the expression of HTT exon1, and furamidine was added to the culture medium. Cells were then cultured for $24 \mathrm{~h}$. Cytotoxicity was measured using the Pierce LDH cytotoxicity assay kit (Thermo Fisher) following the manufacturer's instructions.

SDS Gel Electrophoresis, Western Blotting, and Silver Staining. Samples were dissolved 1:1 in SDS-polyacrylamide gel electrophoresis (PAGE) buffer B [40 mM Tris-HCl (pH 6.8), 4\% glycerol, $2 \%$ SDS, $0.01 \%$ bromophenol blue, and $2 \mathrm{mM}$ mercaptoethanol], sonicated, and boiled for $5 \mathrm{~min}$ at $95{ }^{\circ} \mathrm{C}$. Proteins were separated on $10 \%$ SDS gels and blotted onto PVDF membranes (Roche). Blots were blocked in 5\% milk in TBS-T and incubated with the antibodies listed below at $4{ }^{\circ} \mathrm{C}$ overnight. The resulting bands were detected using Pierce ECL Western Blotting Substrate and quantified using AIDA software (Raytest). Statistical analyses were performed using one-way ANOVA with Dunnett's post hoc test to accommodate multiple comparisons or the Student's $t$ test for twogroup comparisons, as appropriate.

The following antibodies were used: anti-FLAG HRP-coupled (Sigma, A8592), anti-HTT (Abcam, ab109115), anti-actin (Cell Signaling Technology, 4967L), anti-Ataxin 2 (BD, 611378), antiAtaxin 3 (Millipore, MAB5360), anti-mouse HRP (dianova, 115-035003), and anti-rabbit HRP (Cell Signaling Technology, 7074).

Silver staining was performed using the SilverQuest Silver Staining Kit (Thermo Scientific) following the manufacturer's instructions.

FRAP-Based Assay for Monitoring Translation in Living Cells. We have previously established a FRAP-based assay for monitoring translation in living cells. ${ }^{12,18}$ In brief, we expressed GFP-fused HTT exon1 with 46 CAG repeats in HeLa cells. It is noteworthy that three stop codons at the end of the GFP sequence were inserted such that the HTT exon1 sequence was located in the $3^{\prime}$-UTR of GFP. This allows measurement of the effects of the HTT exon1 sequence on the RNA level, without having side effects that might occur when translating the expanded CAG repeat into a polyglutamine stretch. First, the GFP signal of the protein that was present in the cell was bleached in the entire cell. After bleaching, the GFP signal was imaged every 5 min for $4 \mathrm{~h}$. The recovering GFP signal correlates with freshly translated GFP-tagged protein. For the analysis, the GFP signal of every cell was analyzed as the sum of the pixel over the area of the cell using Fiji free software. To normalize the results of each cell, the second frame after bleaching was set as point zero and set to $100 \%$. GraphPad Prism 6 software was used for statistical analysis by one-way ANOVA with Dunnett's multiple-comparison test.

Quantification of Intracellular Furamidine. The uptake of furamidine by HeLa cells was measured by ESI mass spectrometry, combining methods described by Wang et al. ${ }^{27}$ and Colletti et al. ${ }^{28}$ HeLa cells cultured in $10 \mathrm{~cm}$ dishes were treated with $50 \mu \mathrm{M}$ furamidine in the medium for $5 \mathrm{~h}$. Cells were washed three times with PBS, trypsinized, pelleted, and resuspended in $100 \mu \mathrm{L}$ of water. Identical dishes were used for cell counting. Furamidine was extracted by addition of $200 \mu \mathrm{L}$ of ice-cold acetonitrile containing $0.1 \%(\mathrm{v} / \mathrm{v})$ formic acid and $10 \mu \mathrm{M}$ pentamidine as an internal standard (ISTD). The precipitate was removed by centrifugation at $21000 \mathrm{~g}$ for $2 \mathrm{~min}$. Extracts were desalted using Pierce C18 spin columns (Thermo Scientific, Darmstadt, Germany) and analyzed by ESI-MS/MS on an HCTultra ion trap instrument (Bruker Daltonik, Bremen, Germany). Samples were directly infused into the electrospray source at $5 \mu \mathrm{L} / \mathrm{min}$ and quantified by multiple-reaction monitoring in positive ion mode, averaging spectra over $1 \mathrm{~min}$. Intensities of the secondary ions relating to furamidine $(\mathrm{m} / z 305.2 \rightarrow 288.0)$ and the ISTD $(\mathrm{m} / z 342.2 \rightarrow$
324.1) were compared to a calibration curve derived from extracts of cell culture medium spiked with the furamidine standard $(0-50 \mu \mathrm{M})$.

To calculate the intracellular concentration, the volume of a single cell was determined by pelleting $4 \times 10^{7}$ cells $(2 \mathrm{~min}$ at $500 \mathrm{~g})$ and measuring the volume of the pellet. The amount of furamidine in the extract was then divided by the total volume of the cells used for extraction. We have performed mass spectrometry with cell volume estimation experiments in three independent biological replicates. The experiments were performed at the same incubation time of $5 \mathrm{~h}$, as this is the incubation time used for FRAP-based assays monitoring translation in living cells.

In Vitro Translation. Luciferase fused to HTT exon1 with 47 CAG repeats in the $3^{\prime}$-UTR was amplified via PCR using the following primers: forward, CCAAGCTTCTAATACGACTCACTATAGGGAGAATGGAAGACGCCAAAAACATA; reverse, GGTCGGTGCAGCGGCTCCTCAGC. The forward primer contained the T7 promoter sequence to allow subsequent in vitro transcription of the PCR product. The PCR product was in vitro transcribed using the T7 RiboMAX Express Large Scale RNA Production System (Promega). In vitro transcribed RNA was purified with phenol and chloroform and subjected to in vitro translation using the Flexi Rabbit Reticulocyte Lysate System (Promega). The amount of in vitro translated firefly luciferase was measured in a luciferase assay using the Luciferase Assay System (Promega).

Luciferase Assay. Pure CAG repeats (50 repeats) were synthesized as synthetic oligonucleotides with XhoI cloning sites and cloned into the $3^{\prime}$-UTR of Renilla luciferase in the psiCHECK-2 vector using XhoI. This allows the analysis of effects mediated by the CAG repeat in the mRNA without being translated into polyglutamine stretches fused to the luciferase. This is important because polyglutamine stretches might make the luciferase insoluble and might therefore influence its activity. The firefly luciferase gene present on the same vector backbone was used as an internal transfection control. HEK293T cells were transfected with the psiCHECK-2 constructs using Lipofectamine 2000 (Thermo Fisher) following the manufacturer's instructions. Four hours after being transfected, cells were washed with fresh medium with or without $25 \mu \mathrm{M}$ furamidine. After $24 \mathrm{~h}$, cells were lysed in passive lysis buffer (Promega). For the luciferase measurements, the dual luciferase assay kit (Promega) was used. Mean values of relative light units of Renilla normalized to firefly luciferase \pm SEM are shown. Statistical differences were calculated using one-way ANOVA followed by Tukey's multiple-comparison test.

Real-Time PCR. Total RNA was isolated using the RNeasy Mini Kit (Qiagen). cDNA was synthesized using the TaqMan reverse transcription reagent kit (Applied Biosystems), and real-time PCR was performed using the SYBRGreen PCR master mix (Applied Biosystems). The PCR was performed in a $7900 \mathrm{HT}$ Real-Time Cycler (Applied Biosystems) using the following conditions: initial denaturation at $95^{\circ} \mathrm{C}$ for $3 \mathrm{~min}$ and 40 cycles of denaturation for $15 \mathrm{~s}$ at $95^{\circ} \mathrm{C}$ followed by annealing and elongation at $60{ }^{\circ} \mathrm{C}$ for $1 \mathrm{~min}$. The run was finalized by a dissociation curve $\left(95^{\circ} \mathrm{C}\right.$ for $15 \mathrm{~s}, 60^{\circ} \mathrm{C}$ for 15 $\mathrm{s}$, and $95^{\circ} \mathrm{C}$ for $15 \mathrm{~s}$ ). Samples were analyzed in quadruplicate. Data shown represent means of relative HTTexon1 RNA levels (normalized to GAPDH) \pm SEM. The following primers were used: GAPDHforward, CCACCCATGGCAAATTCC; GAPDH-reverse, TGGGATTTCCATTGATGACAAG; HTTexon1-forward, CGCGGCCCCGAATT; HTTexon1-reverse, TCTTTGTAGTCCATGGTGGTTCA.

Microscale Thermophoresis (MST) Experiments. MST assays were mainly performed as described by Wienken et al. ${ }^{29}$ For the experiment, Cy5-labeled RNAs of different lengths were used at a concentration of $400 \mathrm{nM}$. Unlabeled furamidine was added in 1:1 serial dilutions while the DMSO concentration was kept constant at $5 \%$ in the final sample. Samples were prepared in a buffer containing $50 \mathrm{mM}$ Tris- $\mathrm{HCl}$ ( $\mathrm{pH} 8.0$ ), $100 \mathrm{mM} \mathrm{KCl}$, and $10 \mathrm{mM} \mathrm{MgCl}_{2}$. The samples were added to standard capillaries and incubated at $25{ }^{\circ} \mathrm{C}$ for $10 \mathrm{~min}$, prior to the MST measurement in a NanoTemper Monolith NT.015T instrument. By plotting furamidine concentration versus thermophoresis jump, we performed curve fitting using Nanotemper Analysis software, and $K_{\mathrm{D}}$ values were determined. The binding free 
energy was derived from the $K_{\mathrm{D}}$ as $\Delta G^{\mathrm{MST}}=R T \ln K_{\mathrm{D}}$, where $R$ is the ideal gas constant and $T$ is the temperature in kelvin.

Metadynamics-Based Free Energy Calculations. The calculations are based on the X-ray structure of the duplex $\mathrm{r}\left[\left(5^{\prime}\right.\right.$ $\mathrm{G}_{1}$ GCAGCAGCC $\left.\left._{10}\right)_{2}\right]$, CAG RNA hereafter (Protein Data Bank entry $3 \mathrm{NJ} 6^{11}$ ), already used as a model for mRNA CAG repeat in our previous work. ${ }^{16}$ The structure of furamidine (Figure 6) has been constructed from scratch using MOLDEN version 4.0.5. ${ }^{30}$ The compounds' protonation state in aqueous solution and at physiological $\mathrm{pH}$ values $(\approx 7.4)$ was determined by predicting the aqueous ionization constants $\left(\mathrm{p} K_{\mathrm{a}}\right)$, using the Marvin (ChemAxon) code. ${ }^{31}$ The compound is protonated on both its terminal tails. The compound structure was then optimized by means of density functional theory calculations at the B3LYP/6-31G (d,p) level, using the Gaussian09 package. $^{32}$ Atomic RESP ${ }^{33}$ charges were derived using the resp module of AMBER after wave function relaxation. The furamidine-CAG RNA complex was modeled following a similar procedure adopted by us in our previous work. ${ }^{16}$ In brief, an educated first guess of the compound's binding poses on $\mathrm{RNA}_{10}$ was obtained using the HADDOCK $2.1^{34-36}$ docking code. The furamidine-CAG RNA complex with the best HADDOCK score was immersed in a $62 \AA x$ $62 \AA \times 43 \AA$ water box for subsequent MD simulation refinement. The Amber $\chi_{\mathrm{OL} 3}+\mathrm{ff} 99 \mathrm{bsc} 0 / \mathrm{GAFF}$ force fields ${ }^{37-39}$ were used for the parametrization of oligonucleotides and the compound, and the TIP3P model was used for water molecules. ${ }^{40} \mathrm{Na}^{+}$and $\mathrm{Cl}^{-}$ions were added to reach electroneutrality at an ionic strength of $0.157 \mathrm{M}$. The ions were modeled with Joung and Cheatham parameters. ${ }^{41}$ A $0.2 \mu \mathrm{s}$ molecular dynamics simulation was performed (using the GROMACS 4.5.6 package and Plumed $\left.1.3^{42-44}\right)$. Periodic boundary conditions were used, and constant temperature-pressure $(T=300 \mathrm{~K} ; P=1$ atm) dynamics have been determined by the Nosé-Hoover ${ }^{45}$ and Andersen-Parrinello-Rahman coupling schemes. Electrostatic interactions were treated using the particle mesh Ewald (PME) algorithm with a real space cutoff of $10 \AA$, the same that was used for van der Waals interactions. Finally, the furamidine-CAG RNA complex underwent $0.9 \mu \mathrm{s}$ well-tempered metadynamics ${ }^{46,47}$ with the same setup used for the MD simulation.

The free energy was calculated as a function of the following collective variables $(\mathrm{CVs})$ : (i) distance $d_{\mathrm{CM}}$ between the centers of mass of the $\mathrm{RNA}_{10}$ and the ligand and (ii) the number of H-bonds $\left(n_{\mathrm{HB}}\right)$ as defined in refs 16 and 48.

The simulation was performed, starting from the last snapshot of the MD simulation, employing the PLUMED 1.3 plugin $^{44}$ in combination with GROMACS 4.5.6. ${ }^{43}$ The initial height of the Gaussian hills was set to $0.12 \mathrm{kcal} / \mathrm{mol}$. The widths of Gaussians were chosen to be $\sim 1 / 3$ of the typical fluctuations of the CVs during the MD simulation, following ref 46 . The deposition time of the biasing Gaussians was fixed to 1 ps. The contribution to the free energy of unbinding from the metadynamics $\left(\Delta G^{\mathrm{WT}-\mathrm{meta}}\right)$ was calculated as the free energy difference between the minimum at a $d_{\mathrm{CM}}$ of $30 \AA$ and the bound state at a $d_{\mathrm{CM}}$ of $\approx 4 \AA$ ( $\mathrm{U}$ and $\mathrm{B}$ in Figure 6, respectively). The contribution for $d_{\mathrm{CM}}$ values of $>30 \AA\left(\Delta G^{\mathrm{PB}}\right)$ was estimated through the nonlinear Poisson-Boltzmann equation by using APBS 1.3. ${ }^{49}$ The total calculated value for the free energy of unbinding was obtained as $\Delta G^{\mathrm{TOT}}=\Delta G^{\mathrm{WT}-\text { meta }}+\Delta G^{\mathrm{PB}}$. The standard state free energy of dissociation was calculated by eq 1 in which:

$$
\Delta G_{\text {calc }}^{0}=\Delta G^{\mathrm{TOT}}-R T \ln \left(\frac{[\mathrm{L}]}{[\mathrm{L}]^{0}}\right)
$$

where $[\mathrm{L}]$ is the concentration of the ligand in our simulation box $(4.7$ $\mathrm{mM}$ in $190000 \AA^{3}$ ) and $[\mathrm{L}]^{0}$ is the standard state concentration of 1 $\mathrm{mol} / \mathrm{L}^{50}$

\section{ASSOCIATED CONTENT}

\section{S Supporting Information}

The Supporting Information is available free of charge on the ACS Publications website at DOI: 10.1021/acschemneuro.8b00027.
Full-length blot of Figure 2a (Figure S1), evidence that furamidine does not affect the protein level of endogenous nonmutant polyglutamine proteins (Figure S2), chemical structures of the 25 molecules selected in this study (Table S1), and details of furamidine binding poses (PDF)

\section{AUTHOR INFORMATION}

\section{Corresponding Authors}

*E-mail: oriana.tabarrini@unipg.it.

*E-mail: g.rossetti@fz-juelch.de.

*E-mail: sybille.krauss@dzne.de.

ORCID $\odot$

Anna Bochicchio: 0000-0002-4169-8332

Giulia Rossetti: 0000-0002-2032-4630

\section{Author Contributions}

F.M., S.M., A.B., K.S., and J.S. contributed equally to this work. S.K., G.R., P.C., O.T., and K.H. planned and supervised the experiments. F.M., S.M., A.B., K.S., J.S., S.W., N.O., J.D., and S.K. conducted the experiments. E.W. provided experimental tools. S.K., A.B., G.R., P.C., O.T., K.H., K.S., and F.M. wrote the manuscript. All authors discussed the results and commented on the manuscript. All authors have given approval to the final version of the manuscript.

\section{Notes}

The authors declare no competing financial interest.

\section{ACKNOWLEDGMENTS}

The authors gratefully acknowledge the computing time granted by the JARA-HPC Vergabegremium and provided on the JARA-HPC Partition part of the supercomputer JURECA at Forschungszentrum Jülich. The authors thank Prof. Ina Vorberg and Dr. Dan Ehninger for careful review of the manuscript.

\section{ADDITIONAL NOTE}

${ }^{a}$ While nucleic acids ${ }^{13}$ are established ligands targeting CAG repeats in vivo, very few studies have been reported so far on the binding of peptides ${ }^{14}$ and small molecules. ${ }^{15}$

\section{REFERENCES}

(1) Jasinska, A., and Krzyzosiak, W. J. (2004) Repetitive sequences that shape the human transcriptome. FEBS Lett. 567, 136-141.

(2) Mirkin, S. M. (2007) Expandable DNA repeats and human disease. Nature 447, 932-940.

(3) Liu, G., and Leffak, M. (2012) Instability of (CTG)n*(CAG)n trinucleotide repeats and DNA synthesis. Cell Biosci. 2, 7.

(4) Gatchel, J. R., and Zoghbi, H. Y. (2005) Diseases of unstable repeat expansion: mechanisms and common principles. Nat. Rev. Genet. 6, 743-755.

(5) Walker, F. O. (2007) Huntington's disease. Lancet 369, 218-228.

(6) Gil, J. M., and Rego, A. C. (2008) Mechanisms of neurodegeneration in Huntington's disease. Eur. J. Neurosci 27, 2803-2820.

(7) Nalavade, R., Griesche, N., Ryan, D. P., Hildebrand, S., and Krauss, S. (2013) Mechanisms of RNA-induced toxicity in CAG repeat disorders. Cell Death Dis. 4, No. e752.

(8) Schilling, J., Griesche, N., and Krauß, S. (2016) Mechanisms of RNA-Induced Toxicity in Diseases Characterised by CAG Repeat Expansions. eLS, John Wiley \& Sons, Ltd., Chichester, U.K.

(9) de Mezer, M., Wojciechowska, M., Napierala, M., Sobczak, K., and Krzyzosiak, W. J. (2011) Mutant CAG repeats of Huntingtin transcript fold into hairpins, form nuclear foci and are targets for RNA interference. Nucleic Acids Res. 39, 3852-3863. 
(10) Galka-Marciniak, P., Urbanek, M. O., and Krzyzosiak, W. J. (2012) Triplet repeats in transcripts: structural insights into RNA toxicity. Biol. Chem. 393, 1299-1315.

(11) Kiliszek, A., Kierzek, R., Krzyzosiak, W. J., and Rypniewski, W. (2010) Atomic resolution structure of CAG RNA repeats: structural insights and implications for the trinucleotide repeat expansion diseases. Nucleic Acids Res. 38, 8370-8376.

(12) Krauss, S., Griesche, N., Jastrzebska, E., Chen, C., Rutschow, D., Achmuller, C., Dorn, S., Boesch, S. M., Lalowski, M., Wanker, E., Schneider, R., and Schweiger, S. (2013) Translation of HTT mRNA with expanded CAG repeats is regulated by the MID1-PP2A protein complex. Nat. Commun. 4, 1511.

(13) Wild, E. J., and Tabrizi, S. J. (2017) Therapies targeting DNA and RNA in Huntington's disease. Lancet Neurol. 16, 837-847.

(14) Zhang, Q., Chen, Z. S., An, Y., Liu, H., Hou, Y., Li, W., Lau, K.f., Koon, A., Ngo, J., and Chan, E. (2018) A peptidylic inhibitor for neutralizing expanded CAG RNA-induced nucleolar stress in polyglutamine diseases. RNA, rna.062703.117.

(15) Kumar, A., Parkesh, R., Sznajder, L. J., Childs-Disney, J. L., Sobczak, K., and Disney, M. D. (2012) Chemical correction of premRNA splicing defects associated with sequestration of muscleblindlike 1 protein by expanded $\mathrm{r}(\mathrm{CAG})$-containing transcripts. ACS Chem. Biol. 7, 496-505.

(16) Bochicchio, A., Rossetti, G., Tabarrini, O., Krauß, S., and Carloni, P. (2015) Molecular view of ligands specificity for CAG repeats in anti-Huntington therapy. J. Chem. Theory Comput. 11, 4911-4922.

(17) Rosta, E., Buchete, N.-V., and Hummer, G. (2009) Thermostat Artifacts in Replica Exchange Molecular Dynamics Simulations. J. Chem. Theory Comput. 5, 1393-1399.

(18) Griesche, N., Pesch, V., Nalavade, R., Weber, S., König, I., Schölling, M., Möhl, C., and Krauß, S. (2017) tFRAP: A FRAP-Based Technique to Monitor Protein Translation in Living Cells. J. Anal. Bioanal. Tech. 8, n/a.

(19) Lansiaux, A., Dassonneville, L., Facompré, M., Kumar, A., Stephens, C. E., Bajic, M., Tanious, F., Wilson, W. D., Boykin, D. W., and Bailly, C. (2002) Distribution of furamidine analogues in tumor cells: influence of the number of positive charges. J. Med. Chem. 45, 1994-2002.

(20) Lansiaux, A., Tanious, F., Mishal, Z., Dassonneville, L., Kumar, A., Stephens, C. E., Hu, Q., Wilson, W. D., Boykin, D. W., and Bailly, C. (2002) Distribution of furamidine analogues in tumor cells: targeting of the nucleus or mitochondria depending on the amidine substitution. Cancer Res. 62, 7219-7229.

(21) Griesche, N., Schilling, J., Weber, S., Rohm, M., Pesch, V., Matthes, F., Auburger, G., and Krauss, S. (2016) Regulation of mRNA translation by MID1: a common mechanism of expanded CAG repeat RNAs. Front. Cell. Neurosci. 10, 226.

(22) Yang, W. Y., Gao, R., Southern, M., Sarkar, P. S., and Disney, M. D. (2016) Design of a bioactive small molecule that targets r(AUUCU) repeats in spinocerebellar ataxia 10. Nat. Commun. 7, 11647.

(23) Siboni, R. B., Bodner, M. J., Khalifa, M. M., Docter, A. G., Choi, J. Y., Nakamori, M., Haley, M. M., and Berglund, J. A. (2015) Biological Efficacy and Toxicity of Diamidines in Myotonic Dystrophy Type 1 Models. J. Med. Chem. 58, 5770-5780.

(24) Laughlin, S., Wang, S., Kumar, A., Boykin, D. W., and Wilson, W. D. (2014) A novel approach using electrospray ionization mass spectrometry to study competitive binding of small molecules with mixed DNA sequences,. Anal. Bioanal. Chem. 406, 6441-6445.

(25) Thuita, J. K., Karanja, S. M., Wenzler, T., Mdachi, R. E., Ngotho, J. M., Kagira, J. M., Tidwell, R., and Brun, R. (2008) Efficacy of the diamidine DB75 and its prodrug DB289, against murine models of human African trypanosomiasis. Acta Trop. 108, 6-10.

(26) Scherzinger, E., Lurz, R., Turmaine, M., Mangiarini, L., Hollenbach, B., Hasenbank, R., Bates, G. P., Davies, S. W., Lehrach, H., and Wanker, E. E. (1997) Huntingtin-encoded polyglutamine expansions form amyloid-like protein aggregates in vitro and in vivo. Cell 90, 549-558.
(27) Wang, M. Z., Saulter, J. Y., Usuki, E., Cheung, Y. L., Hall, M., Bridges, A. S., Loewen, G., Parkinson, O. T., Stephens, C. E., Allen, J. L., Zeldin, D. C., Boykin, D. W., Tidwell, R. R., Parkinson, A., Paine, M. F., and Hall, J. E. (2006) CYP4F enzymes are the major enzymes in human liver microsomes that catalyze the O-demethylation of the antiparasitic prodrug DB289 [2,5-bis(4-amidinophenyl)furan-bis-Omethylamidoxime]. Drug Metab. Dispos. 34, 1985-1994.

(28) Colletti, L. M., Liu, Y., Koev, G., Richardson, P. L., Chen, C. M., and Kati, W. (2008) Methods to measure the intracellular concentration of unlabeled compounds within cultured cells using liquid chromatography/tandem mass spectrometry. Anal. Biochem. 383, 186-193.

(29) Wienken, C. J., Baaske, P., Rothbauer, U., Braun, D., and Duhr, S. (2010) Protein-binding assays in biological liquids using microscale thermophoresis. Nat. Commun. 1, 100.

(30) Schaftenaar, G., and Noordik, J. H. (2000) Molden: a pre- and post-processing program for molecular and electronic structures. $J$. Comput.-Aided Mol. Des. 14, 233.

(31) Marvin, version 5.2 (2009) ChemAxon, Budapest.

(32) Frisch, M. J., Trucks, G. W., Schlegel, H. B., Scuseria, G. E., Robb, M. A., Cheeseman, J. R., Scalmani, G., Barone, V., Mennucci, B., Petersson, G. M., Nakatsuji, H., Caricato, M., Li, X., Hratchian, H. P., Izmaylov, A. F., Bloino, J., Zheng, G., Sonnenberg, J. L., Hada, M., Ehara, M., Toyota, K., Fukuda, R., Hasegawa, J., Ishida, M., Nakajima, T., Honda, Y., Kitao, O., Nakai, H., Vreven, T., Montgomery, J. A., Jr., Peralta, J. E., Ogliaro, F., Bearpark, M., Heyd, J. J., Brothers, E., Kudin, K. N., Staroverov, V. N., Kobayashi, R., Normand, J., Raghavachar, I. K., Rendell, A., Buran, J. C., Iyengar, S. S., Tomasi, J., Cossi, M., Rega, N., Millam, J. M., Klene, M., Knox, J. E., Cross, J. B., Bakken, V., Adamo, C., Jaramillo, J., Gomperts, R., Stratmann, R. E., Yazyev, O., Austin, A. J., Cammi, R., Pomelli, C., Ochterski, J. W., Martin, R. L., Morokuma, K., Zakrzewski, V. G., Voth, G. A., Salvador, P., Dannenberg, J. J., Dapprich, S., Daniels, A. D., Farkas, Ö., Foresman, J. B., Ortiz, J. V., Cioslowski, J., and Fox, D. J. (2009) Gaussian 09, revision D.01, Gaussian, Inc., Wallingford, CT.

(33) Bayly, C. I., Cieplak, P., Cornell, W. D., and Kollman, P. A. (1993) A Well-Behaved Electrostatic Potential Based Method Using Charge Restraints for Deriving Atomic Charges - the Resp Model,. J. Phys. Chem. 97, 10269-10280.

(34) de Vries, S. J., van Dijk, A. D., Krzeminski, M., van Dijk, M., Thureau, A., Hsu, V., Wassenaar, T., and Bonvin, A. M. (2007) HADDOCK versus HADDOCK: new features and performance of HADDOCK2.0 on the CAPRI targets. Proteins: Struct., Funct., Genet. 69, 726-733.

(35) Dominguez, C., Boelens, R., and Bonvin, A. M. (2003) HADDOCK: a protein-protein docking approach based on biochemical or biophysical information. J. Am. Chem. Soc. 125, 17311737.

(36) van Dijk, M., van Dijk, A. D., Hsu, V., Boelens, R., and Bonvin, A. M. (2006) Information-driven protein-DNA docking using HADDOCK: it is a matter of flexibility. Nucleic Acids Res. 34, 33173325.

(37) Case, D. A., Cheatham, T. E., 3rd, Darden, T., Gohlke, H., Luo, R., Merz, K. M., Jr., Onufriev, A., Simmerling, C., Wang, B., and Woods, R. J. (2005) The Amber biomolecular simulation programs,. J. Comput. Chem. 26, 1668-1688.

(38) Perez, A., Marchan, I., Svozil, D., Sponer, J., Cheatham, T. E., 3rd, Laughton, C. A., and Orozco, M. (2007) Refinement of the AMBER force field for nucleic acids: improving the description of alpha/gamma conformers. Biophys. J. 92, 3817.

(39) Zgarbova, M., Otyepka, M., Sponer, J., Mladek, A., Banas, P., Cheatham, T. E., 3rd, and Jurecka, P. (2011) Refinement of the Cornell et al. Nucleic Acids Force Field Based on Reference Quantum Chemical Calculations of Glycosidic Torsion Profiles. J. Chem. Theory Comput. 7, 2886.

(40) Jorgensen, W. L., Chandrasekhar, J., Madura, J. D., Impey, R. W., and Klein, M. L. (1983) Comparison of Simple Potential Functions for Simulating Liquid Water. J. Chem. Phys. 79, 926-935. 
(41) Joung, I. S., and Cheatham, T. E. d. (2008) Determination of Alkali and Halide Monovalent Ion Parameters for Use in Explicitly Solvated Biomolecular Simulations. J. Phys. Chem. B 112, 9020.

(42) Berendsen, H. J. C., Vanderspoel, D., and Vandrunen, R. (1995) Gromacs - a Message-Passing Parallel Molecular-Dynamics Implementation. Comput. Phys. Commun. 91, 43-56.

(43) Pronk, S., Páll, S., Schulz, R., Larsson, P., Bjelkmar, P., Apostolov, R., Shirts, M. R., Smith, J. C., Kasson, P. M., van der Spoel, D., Hess, B., and Lindahl, E. (2013) GROMACS 4.5: a highthroughput and highly parallel open source molecular simulation toolkit. Bioinformatics 29, 845-854.

(44) Bonomi, M., Branduardi, D., Bussi, G., Camilloni, C., Provasi, D., Raiteri, P., Donadio, D., Marinelli, F., Pietrucci, F., Broglia, R. A., and Parrinello, M. (2009) PLUMED: A portable plugin for free-energy calculations with molecular dynamics,. Comput. Phys. Commun. 180, 1961-1972.

(45) Nosé, S. (1984) A molecular dynamics method for simulations in the canonical ensemble,. Mol. Phys. 52, 255.

(46) Barducci, A., Bonomi, M., and Parrinello, M. (2011) Metadynamics. Wiley Interdisciplinary Reviews: Computational Molecular Science 1, 826-843.

(47) Barducci, A., Bussi, G., and Parrinello, M. (2008) Well-tempered metadynamics: a smoothly converging and tunable free-energy method. Phys. Rev. Lett. 100, 020603.

(48) Bonomi, M., Branduardi, D., Bussi, G., Camilloni, C., Provasi, D., Raiteri, P., Donadio, D., Marinelli, F., Pietrucci, F., Broglia, R. A., and Parrinello, M. (2009) LUMED: a portable plugin for free-energy calculations with molecular dynamics. Comput. Phys. Commun. 180, 1961-1972.

(49) Baker, N. A., Sept, D., Joseph, S., Holst, M. J., and McCammon, J. A. (2001) Electrostatics of nanosystems: application to microtubules and the ribosome. Proc. Natl. Acad. Sci. U. S. A. 98, 10037-10041.

(50) Kranjc, A., Bongarzone, S., Rossetti, G., Biarnes, X., Cavalli, A., Bolognesi, M. L., Roberti, M., Legname, G., and Carloni, P. (2009) Docking Ligands on Protein Surfaces: The Case Study of Prion Protein,. J. Chem. Theory Comput. 5, 2565-2573. 